\title{
EFEKTIFITAS MODEL “PC-JeWa” PERAWAT TERHADAP LOYALITAS PASIEN RAWAT INAP
}

\author{
Enni Juliani ${ }^{* *}$ Ressa Andriyani Utami $^{2)}$ \\ ${ }^{1,2)}$ Sekolah Tinggi Ilmu Kesehatan RS Husada, Jakarta Pusat, 10730, Indonesia \\ e-mail: enni@stikesrshusada.ac.id
}

\begin{abstract}
ABSTRAK
Perilaku caring merupakan hal mutlak yang harus dilakukan perawat kepada pasien. Tujuan penelitian ini adalah untuk mengetahui efektifitas perilaku caring perawatan terhadap loyalitas pasien rawat inap rumah sakit. Penelitian ini menggunakan metode kualitatif pendekatan crosssectional dengan jumlah sampel sebanyak 100 orang yang diambil melalui random sampling. Hasil penelitian menunjukkan data bahwa perilaku caring perawat berhubungan secara signifikan terhadap kepuasan pasien ( $p$ value 0,000 , $\mathrm{OR}=11,769)$. Kepuasan pasien juga berhubungan signifikan terhadap loyalitas pasien $(p$ value $0,000, \mathrm{OR}=6,328)$. Perilaku caring berhubungan secara signifikan terhadap loyalitas pasien ( $p$ value $000, \mathrm{OR}=9,913$ ). Dimensi perilaku caring perawat yang dominan adalah:membantu memenuhi kebutuhan pasien sesuai kemampuan dan ketidakmampuan pasien (misal: makan, minum, BAB, BAK, ganti pakaian dan lainnya) dengan nilai koefisien beta $(\mathrm{OR}=3,114)$. Perawat yang bekerja di pelayanan sebaiknya mengoptimalkan pemenuhan kebutuhan dasar untuk meningkatkan loyalitas pasien.
\end{abstract}

Kata kunci: Keberlangsungan rumah sakit; Kepuasan pasien, Kualitas pelayanan; Loyalitas pasien; Perilaku caring.

\begin{abstract}
Caring behavior is an absolute thing that nurses must do to patients. The objective of this study were to determine the effectiveness of caring caring behaviors towards hospital inpatient loyalty. This study used a qualitative method of cross-sectional approach with a total sample of 100 people taken through random sampling. The results showed that nurses caring behavior significantly related to patient satisfaction ( $p$ value 0,000, OR = 11,769). Patient satisfaction was also significantly related to patient loyalty ( $p$ value $0,000, O R=6,328$ ). Caring behavior was significantly related to patient loyalty ( $p$ value O00, OR = 9,913). The dominant nurse caring behavioral dimensions are: helping meet patient needs according to the ability and disability of the patient (for example: eating, drinking, defecating, urinating, changing clothes and others) with a beta coefficient value $(O R=3.114)$. Nurses who work in services should optimize the fulfillment of basic needs to increase patient loyalty.
\end{abstract}

Keywords: Caring behavior; Hospital sustainability; Patient loyalty; Patient satisfaction; Service quality.

Jurnal Kesehatan Holistic/ Volume 4/ Nomor 1/Januari 2020

(ISSN: 2548-1843, EISSN: 2621-8704) 


\section{PENDAHULUAN}

Bagian integral dari pelayanan kesehatan di rumah sakit adalah pelayanan keperawatan dimana tenaga keperawatan merupakan tulang punggung rumah sakit yang bekerja selama 24 jam penuh dalam sehari. Pelayanan keperawatan yang diberikan oleh seorang perawat sangat mempengaruhi mutu asuhan keperawatan yang akan diterima oleh klien. Mutu pelayanan kesehatan diukur dari kepuasan klien terhadap pelayanan kesehatan dan yang terbesar adalah pelayanan keperawatan (Mahon, 1996; Obsert, 1984 dalam Wolf, 2003). Lebih lanjut disebutkan kepuasan klien pada pelayanan kesehatan di rumah sakit merupakan indikator penting terhadap mutu, pelayanan yang diberikan (Jointer, 1996; Niles et al, 1996 dalam Wolf, 2003).

Sejak munculnya keperawatan modern, caring merupakan inti atau fokus dalam pelayanan keperawatan. Theory of Human Caring Jean Watson menekankan dimensi moral dan etik pada caring. Ia mendasari teori caring dan human care pada asumsi bahwa kesehatan menunjuk pada keserasian atau keselarasan pikiran, tubuh dan roh/jiwa sebagai kesatuan yang utuh dan diekspresikan oleh kecocokan atau kesesuaian antara apa yang dimengerti dan bagaimana pengalaman yang dialami (Kim and Kollak, 1999 dalam Peery, 2006). Watson (2004), menyatakan caring adalah esensi dari keperawatan dan merupakan fokus serta sentral dari praktik keperawatan yang dilandaskan pada nilai-nilai kebaikan, perhatian, kasih terhadap diri sendiri dan orang lain serta menghormati keyakinan spiritual klien.

Menurut Leininger (1997, dalam Watson, 2004), perilaku caring dapat terlihat pada perawat antara lain, memberi rasa nyaman, perhatian kasih sayang, peduli, pemeliharaan kesehatan, memberi dorongan, empati, minat, cinta, percaya, melindungi, kehadiran, mendukung, memberi sentuhan dan siap membantu serta mengunjungi klien. Kesepuluh karatif tersebut adalah pembentukan sistem nilai humanistic 
dan altruistik, menanamkan sikap penuh pengharapan (Faith hope), menumbuhkan sensitifitas terhadap diri dan orang lain, mengembangkan hubungan saling percaya dan membantu, meningkatkan dan menerima ekspresi perasaan positif dan negatif klien, menggunaan metode secara sistematis dalam penyelesaian masalah untuk pengambilan keputusan, meningkatkan pembelajaran dan pengajaran interpersonal, menciptakan lingkungan fisik, mental, sosiokultural, dan spritual yang mendukung, memenuhi kebutuhan dasar manusia dengan penuh penghargaan dalam rangka mempertahankaaan keutuhan dan martabat manusia dan mengijinkan untuk terbuka pada eksistensial fenomonological agar pertumbuhan diri dan kematangan jiwa klien dapat dicapai.

Hasil survey kepuasan pelanggan rumah sakit kebanyakan keluhan menyangkut tentang petugas termasuk perawat, disebutkan tidak profesional dalam memberikan pelayanannya, perawat tidak ramah, tidak peduli dan kurang kompeten dalam menjalankan pelayanan terhadap pasien dan keluarga padahal sangat signifikan hubungan antara perilaku caring perawat dengan kepuasan pasien di ruang rawat inap (Darmawan, 2015). Hal ini didukung oleh penelitia yang dilakukan oleh (Manurung, 2013) dalam Persepsi Pasien Terhadap Perilaku Caring Perawat di Ruang Rawat Inap Rumah Sakit. Hasil penelitian menyimpulkan bahwa faktor yang berhubungan dengan persepsi pasien terhadap perilaku caring perawat adalah kebutuhan caring dan perilaku caring perawat dimana atribut kepuasan pasien dalam konteks perawatan kesehatan berupa sikap penyedia, kompetensi teknis, aksesibilitas dan kemajuan (Ng \& Luk, 2019).

Loyalitas secara umum diartikan sebagai kepatuhan dari seseorang kepada seseorang atau lembaga/institusi yang disenanginya. Namun loyalitas dalam arti yang lebih luas sering juga diartikan sebagai kesetiaan seseorang atas suatu produk, baik barang maupun 
jasa tertentu dan merupakan manifestasi dan kelanjutan dari kepuasan konsumen dalam menggunakan fasilitas maupun jasa pelayanan yang diberikan oleh suatu perusahaan, serta untuk tetap menjadi konsumen dari perusahaan tersebut (James 2007).

Loyalitas dapat juga diartikan sebagai persentase dari orang yang pernah membeli barang/ jasa dalam kerangka waktu tertentu dan melakukan pembelian selanjutnya secara berulang-ulang. Alasan untuk tetap tertarik terhadap suatu produk yang akan mengarahkan pelanggan untuk berminat membeli ulang adalah pengalaman yang memuaskan terhadap produk/ jasa tersebut (Hizrani, 2003).

Menurut (Griffin, 2003) loyalitas seseorang umumnya lebih mengarah pada suatu kebiasaan yang ditujukan pada pembeliaan secara terus menerus yang didasarkan pada unit pengambilan keputusan yang telah teruji. (Kotler, 2012) menyimpulkan bahwa produk jasa umumnya memiliki ciri kualitas berdasarkan kepercayaan yang mengakibatkan konsumen jasa lebih mengandalkan pada kabar dari mulut ke mulut (orang ke orang), dan konsumen juga lebih memperhatikan harga, pemberi jasa dan isyarat fisik untuk menilai kualitas jasa sehingga konsumen akan sangat loyal bila pemberi jasa layanan tersebut memuaskan mereka.

Selanjutnya (Kotler, 2012) mengklasifikasikan tahapan loyalitas seseorang kedalam delapan tahapan antara lain: Suspects, Prospects; First Time Consumens; Repeat Custome Client; Members; Advocates. Berbeda halnya dengan Kotler yang membagi tahapan loyalitas menjadi 8 tahapan, Baloglu (2002) membagi tingkatan loyalitas hanya dalam 4 (empat) tingkatan, tingkatan tersebut didasarkan pada penilaian perilaku dan kebiasaan orang tersebut, antara lain : High (true) loyalty, Latent loyalty, Spurious/artificial loyalty, Low loyalty.

Menurut Kotler (2012) persepsi terhadap kualitas pelayanan harus dimulai dari kebutuhan pelanggan 
dan berakhir pada persepsi pelanggan. Kualitas pelayanan yang baik bukanlah berdasarkan sudut pandang pihak penyelia pelayanan, melainkan berdasarkan sudut pandang pelanggan. Pendapat

Bachtiar dkk (2002) menyatakan bahwa kepuasan pasien adalah suatu keadaan dimana kebutuhan, keinginan dan harapan pasien dapat dipenuhi melalui produk/jasa yang diterimanya, yang berarti bahwa keputusan pasien sangat ditentukan oleh persepsi pasien tentang hal-hal yang dibutuhkan dan diinginkannya selama proses pelayanan kesehatan. (Bologlu, 2002) menambahkan untuk mengukur loyalitas pelanggan didasarkan atas dua variabel (perilaku dan sikap) bisa dikategorikan menjadi, yaitu: Kepercayaan (trust), Keterikatan secara emosional (Psychological) emotional commitment), Biaya peralihan (Switching cost), Publisitas dari mulut ke mulut (word of mouth)dan Kerja sama (cooperation). Kualitas memberikan dorongan kepada pasien untuk menjalin ikatan hubungan yang lebih kuat dengan rumah sakit dan pada gilirannya dapat menciptakan kesetiaan atau loyalitas pelanggan, maka Rumah Sakit akan melakukan strategi promosi kesehatan baik advokasi, bina suasana dan pemberdayaan masyarakat (Maulana, 2009).

Kualitas memiliki hubungan yang erat dengan kepuasan pasien, dimana kualitas memberikan dorongan kepada pasien untuk menjalin ikatan hubungan yang lebih kuat dengan rumah sakit dan pada gilirannya kepuasan pasien dapat menciptakan kesetiaan atau loyalitas pelanggan kepada rumah sakit yang memberikan kualitas memuaskan tersebut (Tjiptono, 2004). Sementara Bachtiar dkk (2002) menyatakan bahwa kepuasan pasien adalah suatu keadaan dimana kebutuhan, keinginan dan harapan pasien dapat dipenuhi melalui produk/jasa yang diterimanya, yang berarti bahwa keputusan pasien sangat ditentukan oleh persepsi pasien tentang hal-hal yang dibutuhkan dan diinginkannya selama proses pelayanan kesehatan. 
Loyalitas pasien dipengaruhi oleh kepuasan pasien terhadap kualitas pelayanan secara keseluruhan dimana pasien yang merasa puas akan kembali menggunakan jasa pelayanan, serta merekomendasikan kepada orang lain (E. Sitayani, Hamzah, \& Yusran Amir, 2014)

Berlandaskan pentingnya terpenuhinya kepuasan pasien selama menjalani rawat inap dimana hal ini dapat diperoleh dari sikap pedulu atau perilaku caring perawat dan sarana pelayan lainnya yang ad di rumah sakit dan perlunya upaya untuk menjaga keberlanjutkan pelayanan kesehatan di rumah sakit (loyalitas pasien) maka peneliti tertarik untuk melakukan penelitian tentang perilaku caring perawat terhadap loyalitas pasien rawat inap di rumah sakit.

Adapun tujuan penelitian ini adalah:

(a) Mengidentifikasi pelaksanaan perilaku caring perawat; (b) Mengidentifikasi loyalitas pasien yang dirawat di ruang rawat inap; (c) Mengkaji dimensi perilaku caring yang paling dominan terhadap loyalitas pasien rawat inap; (d) Menganalisis hubungan perilaku caring perawat dengan loyalitas pasien rawat inap.

\section{METODE PENELITIAN}

Penelitian ini merupakan metode kuantitatif, dengan pendekatan deskriptif, karena penelitian ini bertujuan memperoleh gambaran lengkap mengenai efektifitas perilaku caring perawat terhadap loyalitas pasien. Proses pelaksanaan penelitian dimulai dari studi literatur, pengumpulan data dan informasi, identifikasi masalah, dilanjutkan dengan pengumpulan data ke pasien dengan menggunakan kuesioner tentang perilaku caring perawat dan loyalitas pasien.

$\begin{array}{lrr}\text { Kuesioner } & \text { perilaku } & \text { caring } \\ \text { menggunakan } & \text { kuesioner } & \text { yang }\end{array}$ dikembangkan dengan mengacu kepada konsep atau teori perilaku caring (10 Caritas) menurut Jean Watson (Wei \& Watson, 2019) dan kuesioner tentang Loyalitas pasien atau pelanggan menggunakan kuesioner. Adapun pertanyaan 
mencakup sederetan pertanyaan dan menggunakan skala likert dan sebelum digunakan dilakukan uji validitas dan reliabilitas terhadap instrumen.

Adapun populasi pada penelitian ini adalah pasien rawat inap di 4 RS di wilayah DKI Jakarta (Pusat, Timur, Selatan dan Utara). Teknik yang digunakan untuk penentuan sampel menggunakan probability sampling cara cluster sampling, yakni metode pemilihan sampel dengan randomisasi (acak) dilakukan terhadap individu anggota populasi, random dilakukan pada setiap RS Pendidikan yang ada atau pengambilan sampel berdasarkan wilayah misalnya Bagian Pusat, Barat, Timur dan seterusnya (Dharma, 2011; Sastroasmoro \& Ismail, 2014).

Data yang diperoleh dianalisis menggunakan teknis analisis data statistik yaitu dimulai dari analisis univariat terhadap beberapa variabel pertanyaan, dilanjutkan dengan uji hipotesis melalui analisa bivariat (analisis hubungan perilaku caring perawat dengan kepuasan pasien, analisa kepuasan pasien dengan loyalitas pasien dan analisis hubungan perilaku caring perawat dengan loyalitas pasien). Untuk mengetahui dimensi caring yang paling dominan maka dilanjutkan dengan analisa multivariat (pemodelan).

Langkah pertama yang harus dilakukan adalah menyeleksi setiap variabel yang dapat masuk dalam analisis multivariat (pemodelan) melalui seleksi bivariat. Setiap variabel yang memiliki nilai $p$ kurang dari 0,25 dilanjutkan dalam analisis multivariat, sedangkan variabel dengan nilai $\mathrm{p}$ lebih besar dari 0,25 tidak dimasukkan analisis multivariat. Selanjutnya pemodelan awal dan uji interaksi variabel independen dan kandidat sub variabel. Kandidat interaksi meliputi interaksi antara variabel kinerja dengan semua kandidat variabel perancu. Uji interaksi merupakan pengeluaran secara bertahap variabel interaksi yang mempunyai nilai $\mathrm{p}>$ 0,05 . Pengeluaran tersebut dimulai dari variabel interaksi dengan nilai $\mathrm{p}$ 
value terbesar. Diakhiri dengan pemodelan akhir.

\section{HASIL DAN PEMBAHASAN}

Hasil utama yang diperoleh dari penelitian ini adalah Efektifitas perilaku caring perawat terhadap loyalitas pasien pada RS yang telah memberikan pelayanan rawat inap. Berikut disajikan dalam bentuk tabel.

Tabel 1

Analisis hubungan perilaku caring perawat dengan kepuasan pasien $(\mathrm{n}=100)$

\begin{tabular}{|c|c|c|c|c|c|c|c|c|}
\hline \multirow{3}{*}{ Perilaku caring } & \multicolumn{4}{|c|}{ Kepuasan pasien } & \multirow{2}{*}{\multicolumn{2}{|c|}{ Total }} & \multirow{3}{*}{ OR $(95 \% \mathrm{CI})$} & \multirow{3}{*}{ P Value } \\
\hline & \multicolumn{2}{|c|}{ Kurang Pua } & \multicolumn{2}{|c|}{ Puas } & & & & \\
\hline & $\mathrm{N}$ & $\%$ & $\mathrm{n}$ & $\%$ & $\mathrm{~N}$ & $\%$ & & \\
\hline Kurang caring & 17 & 85 & 3 & 15 & 20 & 100 & \multirow{3}{*}{$\begin{array}{l}11,769 \\
(3,164- \\
43,773)\end{array}$} & \multirow{3}{*}{0,000} \\
\hline Caring & 26 & 32,5 & 54 & 67,5 & 80 & 100 & & \\
\hline Total & 43 & 43 & 57 & 57 & 100 & 100 & & \\
\hline
\end{tabular}

Hasil analisis data menunjukkan bahwa perilaku caring berhubungan secara signifikan terhadap kepuasan pasien ( $\mathrm{p}$ value 0,000). Berdasarkan hasil analisis diperoleh juga nilai $\mathrm{OR}=11,769$, artinya perawat yang memiliki perilaku caring perawat berpeluang meningkatkan tingkat kepuasan pasien sebanyak 11,769 pada ruang rawat inap di RS. Oleh karena itu untuk meningkatkan kepuasan pasien, rumah sakit perlu meningkatkan upaya mereka dalam nilai yang dirasakan, kepercayaan, dan kualitas layanan (Dachyar, Farizal, \& Minar, 2018) dan salah satu yang paling penting adalah komunikasi (Ribka P. Wulur, Ardiansa A.T. Tucunan, 2019). Bagaimanapun perilaku caring perawat merupakan salah satu aspek penting dalam memenuhi kepuasan pasien, dan hal ini menjadi salah satu indikator kualitas pelayanan disebuah rumah sakit (Suweko \& Warsito, 2019). 
Tabel 2

Analisis hubungan kepuasan pasien dengan loyalitas pasien $(n=100)$

\begin{tabular}{|c|c|c|c|c|c|c|c|c|}
\hline \multirow{3}{*}{$\begin{array}{c}\text { Kepuasan } \\
\text { pasien }\end{array}$} & \multicolumn{4}{|c|}{ Loyalitas pasien } & \multirow{2}{*}{\multicolumn{2}{|c|}{ Total }} & \multirow{3}{*}{ OR $(95 \% \mathrm{CI})$} & \multirow{3}{*}{$\mathrm{P}$ Value } \\
\hline & \multicolumn{2}{|c|}{ Kurang Loyal } & \multicolumn{2}{|c|}{ Loyal } & & & & \\
\hline & $\mathrm{N}$ & $\%$ & $\mathrm{n}$ & $\%$ & $\mathrm{~N}$ & $\%$ & & \\
\hline Kurang puas & 27 & 62,8 & 26 & 32,7 & 43 & 100 & \multirow{3}{*}{$\begin{array}{l}6,328 \\
(2,605- \\
15,373)\end{array}$} & \multirow{3}{*}{0,000} \\
\hline Puas & 12 & 21,1 & 45 & 78,9 & 57 & 100 & & \\
\hline Total & 39 & 39 & 61 & 61 & 100 & 100 & & \\
\hline
\end{tabular}

Hasil analisis data menunjukkan

bahwa kepuasan pasien

berhubungan secara signifikan

terhadap loyalitas pasien ( $\mathrm{p}$ value

0,000). Berdasarkan hasil analisis diperoleh juga nilai $\mathrm{OR}=6,328$, artinya pasien yang memiliki kepuasan yang baik ketika dirawat di RS akan meningkatkan loyalitas pasien sebanyak 6,328 pada ruang rawat inap di RS. Hal senada disampaikan oleh (Dachyar et al., 2018) bahwa kepuasan dan kepercayaan adalah dua faktor kuat yang mempengaruhi loyalitas pasien. Kepuasan pelanggan menciptakan loyalitas yang dipegang tanpa keyakinan (Wolter, Bock, Smith, \& Cronin, 2017). Kepuasan pasien tidak terlepas dari baiknya kualitas proses, kualitas infrastruktur, dan kualitas interaksi (Andria Devi dan Wisnu Untoro, 2019). Bahkan saat ini kepuasan pelanggan adalah inti dari pemasaran modern yang berorientasi kepada pelanggan (customer) dimana perawat dan mahasiswa keperawatan memiliki persepsi yang sama tentang perilaku peduli ini (Aupia, Lee, Liu, Wu, \& Mills, 2018)

Tabel 3

Analisis hubungan perilaku caring perawat dengan loyalitas pasien $(n=100)$

\begin{tabular}{|c|c|c|c|c|c|c|c|c|}
\hline \multirow{3}{*}{ Perilaku caring } & \multicolumn{4}{|c|}{ Loyalitas pasien } & \multirow{2}{*}{\multicolumn{2}{|c|}{ Total }} & \multirow{3}{*}{ OR $(95 \% \mathrm{CI})$} & \multirow{3}{*}{ P Value } \\
\hline & \multicolumn{2}{|c|}{ Kurang Loyal } & \multicolumn{2}{|c|}{ Loyal } & & & & \\
\hline & $\mathrm{N}$ & $\%$ & $\mathrm{n}$ & $\%$ & $\mathrm{~N}$ & $\%$ & & \\
\hline Kurang caring & 16 & 80 & 4 & 20 & 20 & 100 & \multirow{3}{*}{$\begin{array}{l}9,913 \\
(2,992- \\
32,842)\end{array}$} & \multirow{3}{*}{0,000} \\
\hline Caring & 23 & 28,8 & 57 & 71,3 & 80 & 100 & & \\
\hline Total & 39 & 39 & 61 & 61 & 100 & 100 & & \\
\hline
\end{tabular}


Hasil analisis data menunjukkan bahwa perilaku caring berhubungan secara signifikan terhadap loyalitas pasien ( $\mathrm{p}$ value 0,000). Berdasarkan hasil analisis diperoleh juga nilai $\mathrm{OR}=9,913$, artinya perawat yang memiliki perilaku caring perawat berpeluang meningkatkan tingkat loyalitas pasien sebanyak 9,913 pada ruang rawat inap di rumah sakit.

Senada dengan hasil penelitian yang dilakukan (Q-X Yang and J Chen, 2018) dimana pasien menunjukkan kepercayaan positif terhadap dokter yang merawat mereka maka kepercayaan pasien akan memengaruhi loyalitas mereka ke rumah sakit, menunjukkan bahwa peningkatan kepercayaan pasien tidak hanya akan meningkatkan kepatuhan pasien tetapi juga bisa membantu meningkatkan reputasi rumah sakit. Tidak ada hubungan yang signifikan secara statistik antara tingkat loyalitas pasien dan indikator organisasi, teknologi informasi dan manajemen pengetahuan namun, ada hubungan yang signifikan secara statistik antara loyalitas dan dimensi proses layanan (Hajikhani, Tabibi, \&
Riahi, 2015). Hal ini menunjukkan ketika tenaga kesehatan yang memberikan pelayanan langsung ke pasien mampu menimbulkan penilaian positif/persepsi positif pada pasien atas perilaku mereka selama memberikan pelayanan kesehatan kepada pasien rawat inap maka akan meningkatkan kepercayaan/loyalitas pasien untuk kembali menggunakan jasa layanan tersebut.

Banyak perawat merangkul dan membuktikan semangat dengan orang-orang untuk siapa mereka memberikan perhatian, dan ini bergantung pada kredibilitas indera mereka (Wei \& Watson, 2019) bahkan ketika faktor lain dapat mempengaruhi perawat dalam melaksanakan perilaku caring yang salah satunya adalah beban kerja perawat (Juliani, 2017). Kemudian untuk mengetahui dimensi perilaku caring yang paling dominan yang menentukan loyalitas pasien rawat inap diketahui dengan melakukan tahap pemodelan akhir, setelah sebelumnya melewati tahap seleksi kandidat, pemodelan awal 
multivariat, pemodelan awal dan uji bentuk tabel.

interaksi. Berikut hasilnya dalam

Tabel 4

Pemodelan Akhir ( $\mathrm{n}=100)$

\begin{tabular}{|c|c|c|c|c|c|}
\hline \multirow{2}{*}{ Variabel } & \multirow{2}{*}{ B } & \multirow{2}{*}{$\mathrm{P}$} & \multirow{2}{*}{ OR } & \multicolumn{2}{|c|}{$95 \%$ C.I for EXP (B) } \\
\hline & & & & Lower & Upper \\
\hline $\begin{array}{l}\text { Perawat menunjukkan sikap baik } \\
\text { pada saya }\end{array}$ & $-1,126$ & 0,010 & 0,324 & 0,138 & 0,762 \\
\hline $\begin{array}{l}\text { Perawat mengajarkan cara } \\
\text { memenuhi kebutuhan diri saya } \\
\text { secara mandiri yang sesuai dengan } \\
\text { masalah dan kemampuan saya. }\end{array}$ & 0,745 & 0,196 & 2,107 & 0,680 & 6,529 \\
\hline $\begin{array}{l}\text { Perawat membantu memenuhi } \\
\text { kebutuhan saya sesuai dengan } \\
\text { kemampuan atau ketidakmampuan } \\
\text { saya (misal: makan, minum, bab, } \\
\text { bak, ganti pakaian dan lainnya) }\end{array}$ & 1,462 & 0,022 & 3,114 & 1,181 & 8,156 \\
\hline
\end{tabular}

Berdasarkan hasil pemodelan akhir analisis multivariat, dapat disimpulkan bahwa Perilaku caring perawat membantu memenuhi kebutuhan saya sesuai dengan kemampuan atau ketidakmampuan saya (misal: makan, minum, bab, bak, ganti pakaian dan lainnya) dengan nilai koefisien beta $(\mathrm{OR}=3,114)$ merupakan faktor yang paling berkonstribusi terhadap loyalitas pasien rawat inap di RS.

Makan, minum, BAB, BAK, ganti pakaian dan sebagainya adalah merupakan kebutuhan paling dasar manusia yaitu unsur-unsur yang dibutuhkan oleh manusia dalam mempertahankan keseimbangan fisiologis maupun psikologis, yang bertujuan untuk mempertahankan kehidupan dan kesehatan. Hal ini menunjukkan sesuai dengan hirarkie kebutuhan dasar manusia menurut Abraham Maslow (Wilkinson \& Judith, 2016)

\section{KESIMPULAN DAN SARAN}

Berdasarkan hasil pembahasan maka dapat disimpulkan bahwa perilaku caring berhubungan secara signifikan terhadap kepuasan pasien. Kepuasan pasien berhubungan secara signifikan terhadap loyalitas pasien. Perilaku 
caring berhubungan secara signifikan terhadap loyalitas pasien. Dimensi perilaku caring yang dominan adalah perilaku caring perawat membantu memenuhi kebutuhan saya sesuai dengan kemampuan atau ketidakmampuan saya (misal: makan, minum, bab, bak, ganti pakaian dan lainnya).

Berdasarkan hasil penelitian ini maka beberapa saran yang dapat peneliti sampaikan bagi perawat Ruang Rawat Inap adalah dalam memberikan asuhan atau pelayanan kepeerawatan maka pememnuhan kebutuhan dasar manusia adalah menjadi prioritas karena dapat meningkatkan tingkat kepuasan pasien rawat inap dan mempengaruhi signifikan terhadap loyalitas pasien. Saran bagi Divisi Keperawatan RS adalah bahwa kepuasan pasien berhubungan signifikan terhadap pelayanan keperawatan yang ditunjukkan dalam perilaku caring perawat, sehingga pembekalan dan pembinaan tentang perilaku caring perawat perlu disampaikan kepada para perawat dan dilakukannya monevin secara kontinu terhadap pelayanan keperawatan.

Saran bagi pendidik bahwa perilaku Caring agar menjadi bagian dari ilmu dasar keperawatan dan menjadi bagian dari kurikulum yang harus disampaikan kepada peserta didik sebelum turun ke lahan praktek nyata. Saran bagi peneliti lanjutan bahwa penelitian selanjutnya sebaiknya dapat menambah jumlah responden dan berasal dari tiap-tiap unit ruang perawatan sehingga konsep yang dimodelkan dapat ditingkatkan generalisasinya serta memberikan gambaran yang lebih objektif dari seluruh ruang rawat inap rumah sakit. Penelitian selanjutnya sebaiknya menambahkan variabel-variabel lain yang belum ada dalam penelitian ini sehingga dapat menyempurnakan pemahaman terhadap faktor-faktor yang mempengaruhi perilaku caring perawat, kepuasan, dan loyalitas pasien seperti: beban kerja perawat, budaya organisasi, meliputi: komunikasi, pelatihan dan pengembangan, reward, pengambilan risiko, kerjasama dan 
praktik manajemen yang berhubungan dengan prilaku caring

\section{DAFTAR PUSTAKA}

Andria Devi dan Wisnu Untoro, B. (2019). Kepuasan pelanggan memediasi pengaruh kualitas proses, kualitas infrastruktur dan kualitas interaksi terhadap loyalitas pelanggan. Jurnal Ilmiah Manajemen, $9(1)$. https://doi.org/10.22441/mix.20 19.v9i1.003

Aupia, A., Lee, T.-T., Liu, C.-Y., Wu, S.-F. V., \& Mills, M. E. (2018). Caring behavior perceived by nurses, patients and nursing students in Indonesia. Journal of Professional Nursing, 34(4), 314-319.

https://doi.org/10.1016/j.profnur s.2017.11.013

Bologlu. (2002). No TitleDimension of Customer Loyalty, Cornell Hotel and Restaurant

Administration Quarterly.

Dachyar, M., Farizal, \& Minar, I. P. (2018). Patients' Loyalty Improvement in Public Hospital. In MATEC Web of perawat belum menjadi fokus dalam penelitian sebelumnya.

Conferences (Vol. 248). EDP Sciences.

https://doi.org/10.1051/matecco $\mathrm{nf} / 201824803015$

Darmawan. (2015). No TitleHubungan perilaku caring perawat terhadap tingkat kepuasan pasien rawat inap di RSUD Klungkung. Retrieved from

https://media.neliti.com/media/p ublications/76396-ID-

hubungan-perilaku caringperawat-terhadapkepuasanpasien-rawat-inap.pdf

E. Sitayani, J., Hamzah, A., \& Yusran Amir, M. (2014). Hubungan kepuasan dengan loyalitas pasien rawat inap rumah sakit inap rumah sakit umum daerah kabupaten Pangkep. Retrieved from http://repository.unhas.ac.id/han dle/123456789/10485

Griffin. (2003). Customer Loyalty. Jakarta: Erlangga.

Hajikhani, S., Tabibi, S. J., \& Riahi, L. (2015). The Relationship 
Between the Customer

Relationship Management and

Patients' Loyalty to Hospitals.

Global Journal of Health

Science, $\quad 8(3), \quad 65-71$.

https://doi.org/10.5539/gjhs.v8n 3p65

Juliani, E. (2017). Pengaruh beban kerja dengan pelaksanaan perilaku caring perawat pelaksana menurut persepsi pasien di RS Husada Jakarta. Jurnal Kesehatan Holistic, 1, 31-44.

https://doi.org/https://doi.org/10 $.33377 / j k h . v 1 i 1.29$

Manurung, S. (2013). No TitlePersepsi Pasien Terhadap Perilaku Caring Perawat di Ruang Rawat Inap Rumah Sakit. Retrieved from http://media.neliti.com/media/p ublications/39802-ID-persepsipasien-terhadap-perilakucaring-perawat-di-ruang-rawatinap-rumah-sakit.pdf

Ng, J. H. Y., \& Luk, B. H. K. (2019). Patient satisfaction: Concept analysis in the healthcare context. Patient Education and Counseling, 102(4), 790-796. https://doi.org/10.1016/j.pec.20

18.11 .013

P, K. (2012). Manajemen

Pemasaran, Analisis,

Perencanaan dan

Pengendalian.

(A.

A.

Hermawan, Ed.) (9th ed.).

Jakarta: Prehallindo.

Q-X Yang and J Chen. (2018). Patient's trust in physician and its influence on patient's loyalty to hospitals in Guangzhou, China: a cross sectional study. The Lancet, 392, S16. https://doi.org/10.1016/s01406736(18)32645-x

Ribka P. Wulur, Ardiansa A.T. Tucunan, F. R. R. M. (2019). Hubungan antara komunikasi dokter pasien dengan kepuasan pasien rawat inap di rumah sakit Bhayangkara tingkat III Manado. Kesmas, vol 8 no. Retrieved from https://ejournal.unsrat.ac.id/inde x.php/kesmas/article/view/2570 4

Suweko, H., \& Warsito, B. E. (2019). Hubungan perilaku caring perawat dengan kepuasan pasien diruang rawat inap: 
Litertur review. Jurnal Ilmu

Keperawatan Dan Kebidanan, 10(1),

243.

https://doi.org/10.26751/jikk.v1

$0 \mathrm{i} 1.532$

Wei, H., \& Watson, J. (2019).

Healthcare interprofessional team members' perspectives on human caring: A directed content analysis study. International Journal of Nursing Sciences, 6(1), 17-23. https://doi.org/10.1016/j.ijnss.20 18.12.001
Wolter, J. S., Bock, D., Smith, J. S., \& Cronin, J. J. (2017). Creating Ultimate Customer Loyalty Through Loyalty Conviction and Customer-Company Identification. Journal of Retailing, 93(4), 458-476. https://doi.org/10.1016/j.jretai.2 017.08.004 